\title{
Ethnicity in Motion: constructing Brasilidade by giving former migrants autochthonous status*
}

Konstanze Jungbluth ${ }^{a}$

\begin{abstract}
The paper presents the postmodern perspective on autochthony from a theoretical approach. The previously held contrast between allochthonous and autochthonous people has undergone a change; nowadays, researchers propose that the two qualities form the poles of a continuum, where different grades of being autochthones may be distinguished. As has Canada, the Brazilian government has recently paved the way, conceding the status of autochthony to language communities living for at least three generations in the country. By recognizing cultural, and at the same time linguistic diversity as an important essential part of the process of constructing the new image of being Brazilian, a brasilidade (LESSER, 2015), the unique language use developed by descendents of European migrants, is now regarded as part of the historical and artistic immaterial patrimony in South America.
\end{abstract}

Keywords: Brazil. Language use. Autochthonous. Language politics. Bilingualism.

\footnotetext{
* On behalf of the English version, I would like to thank Todd Ehresmann for his great efforts in correcting my manuscript. Of course all remaining errors are mine.
} 


\section{Introduction}

The term autochthonous goes back to Ancient Greece times. However, this term, used especially in sociolinguistic theory in connection with the discussion of minorities' rights, has undergone some fundamental reinterpretations. The most recent proposal (TACKE, 2015) consists of the image of a gradatum. Earlier antonyms autochthonous and allochthonous did indeed form a sharp contrast, with communities and their members being regarded either as the former or as the latter; nowadays, however, grades of being autochthonous have been introduced. In modern times, countries such as Canada or Brazil, which have been, and still are especially attractive destinations for migrants, are ready to concede the status of being autochthonous to language communities living for at least three generations in the country. The discussion connects theoretical implications with results of case studies in Southern Brazil, in addition to recent changes in language politics in this country.

The contribution unfolds its subject in five parts. Firstly, I introduce the term autochthonous and the two closely related terms indigenous and aboriginal. Secondly, I focus on the autochthonous speakers, their perceptions, their environment and their social identity. Furthermore, the allochthones themselves are the topic. In this part, I discuss the proposal following Tacke (2015). I add a small side note to familiarize the interdisciplinary reader with the use of the same attribute in the Natural Sciences. After setting the scene theoretically in the final part, I compare two German communities - one in the former Soviet Union and the other in Brazil - to show the difficulties neoautochthonous communities must face in the different parts of the world to which their forefathers migrated. Their challenges are different, as in Europe the conditions are different from those in Brazil. While remigration is generally an important issue in the post-Soviet context, new language politics in Brazil offer for the first time possibilities to anchor bilingual instruction from the very beginning of (pre-)school. 
${ }^{1}$ The Greek goddess Athena receives the baby Erichthonius from the hands of the earthmother Gaia; cf. image on a stamnos, a greek vase to preserve wine: Staatliche Antikensammlungen, Munich, Inventory $\mathrm{n} \mathrm{u} \mathrm{m} \mathrm{b} \mathrm{e} \mathrm{r} 2413$. Disponível em: <http:// www.mlahanas.de/ Greeks/Mythology/ ErichthoniusSA2413. html>. Acesso em 05/01/2017.

${ }^{2} \mathrm{Cf}$. more details on the myth of Erichthonius may be found at http:// www.mythindex.com/ greek-mythology/E/ Erichthonius.html. Acesso em 05/01/2017.

${ }^{3}$ Athenians are Erechtheidai, sons of Erichthonius, who was the first king of Athens, coming from chthon, the underworld (ROSIVACH, 1987, p. 301).

\section{Autochthonous - Indigenous - Aboriginal}

The definition given in the Tresor de la Langue Française for the term autochthonous in Ancient Greece was: "[d]es premiers habitants qui tindrent le pays d'Attique, lesquels on a depuis appelez autochtones" (TLF, s.v. autochtone), that is, 'The first inhabitants living in the place of Attica were later on called autochthone' (our translation). In particular, the citizens of Athens considered themselves to be descendants of Erichthonius, and therefore as earthborn people ${ }^{1}$. Frozen in the myth $^{2}$ repeated through the generations, they not only established this origin as self-ascribed, but convinced foreigners to accept this feature as forming part of their unique identity as Athenians ${ }^{3}$, while at the same time excluding inhabitants arriving the polis later by foregrounding their distinct ancestry. Consistent with this origin, the term autochthonous refers to earth, which furthermore ended up forming part of the term's etymology.

There are two other closely related terms which are sometimes used in similar contexts: indigenous and aboriginal. The former refers to birth - more precisely to genealogy and the line of descent. The latter foregrounds origin and ancestry. While indigenous is more common for identifying native people living on the American continent, aboriginal often occurs in the collocation aborigines of Australia.

Figure 1. The hierarchy between the three terms and differences among their meanings.

\section{autochthonous}

\section{earth; etymology}

indigenous birth aboriginal

origin 
As shown in figure 1, I consider autochthonous to be a hyperonym with regard to the other two hyponyms. The attribut autoch thonous serves two different functions: It may be directed inwards when used in political and ideological frames to strenghen the belonging (local, regional attachment, Pfaff Czarnecka 2011, 2013); namely, the internal cohesion among the members of a group or a community confirming their collective identity. Secondly, it may be directed outwards by excluding other groups or individuals who arrived later or more recently to the territory claimed by the former:

"Discourses on autochthony and indigeneity" (ZENKER, 2011, p. 63) are performed in the context of minorities, their rights, and ethnic revival in general. Autoctoness [sic!] starts with the premise "that descendants of the original inhabitants of a country should have privileged rights, perhaps even exclusive rights, to its ressources." (KUPER 2003, p. 390).

In the following section, we focus on the speakers of communities involved in this kind of discourse.

\section{The autochthonous speakers}

People are usually aware that others never talk in exactly the same manner as oneself. The heterogenity of expression is based on contrasts, some of them being anchored in diatopic differences usually called dialects; others are based on diastratic differences shown by sociolects or substandards. A third set of distinctions are found in mirroring diaphasic spaces - contrasting [in-]formal language use in public versus private spaces (COSERIU, 1980, p. 112). The chain between the different forms representing these contrasts is usually unidirectional, as shown by processes of language change. Using the example of an Andalusian Spanish utterance overheard in the Metro of Madrid, one may consider its use, firstly, as typical for someone from Malaga referring to the region and its dialect, thus marking the speaker as a traveller from the South. Secondly, by evaluating the utterance as representing diastratic variation, one may consider her or him to be a member of a certain social class with low prestige living in the capital. Thirdly, one can interpret this use as someone expressing oneself in an informal way using a diaphasic variety. This example shows that one and the same form may 
serve different functions: diatopic, diastratic and/or diaphasic variation - and furthermore, that diatopic variation may change to mark a diastratic variation - or in another step a diaphasic variation. Notably, the opposite direction in changes of respectively marked variation is not attested.

I have illustrated this evaluation of the user here to emphasize that the contiguity between language use and place is not 'naturally' given, but culturally constructed. Taking another perspective, one may emphasize similarity, which characterizes syntopic, synstratic and synphasic convergence shown in language use at the same time as well. The linguistic landscape surrounding the speakers is produced by the speech acts in their audible forms, or to a lesser extent in their visual forms when represented in writing. Upon these speech acts, people build their cognitive construction. Speakers may apply the principles of contiguity, e.g. appearance close to one another at the same time, or similarity, or contrast. Especially built upon the principle of contiguity the constructed linguistic-spatial knowledge foregrounds the relation to the place. In doing so, the fact that people are mobile and may change their location relatively easily is not taken into account. If they do change location as in the above example, their way of expression may change its functions, but often keep its form for a long period of time.

\section{Their perceptions}

The perceptions of these speakers are often deceived by the (erroneous) heritage of an "homoglossic" (LÜDI et al., 2008, p. 1) ideology as part of the [European] nation state. In fact, plurilingualism is not only a feature of Switzerland, which is famous for being plurilingual at the level of the nation due to its division into four parts, where French, German, Italian and Ladin enjoy privileged status. However, in most countries of Europe, several languages are in fact spoken within their borders. Within the European context, linguistic diversity can be studied at the level of both official state languages and 'non-national languages' (BARNI; EXTRA, 2008). Again, the widespread misunderstanding that (national) belonging is related to a monolingual language use has not been the rule historically, and even nowadays local forms of speaking 
persist in rural contexts, and new dialects are emerging in urban contexts; all of this shows that a plurilingual societies is common all over Europe.

\section{Their environment}

The way speakers imagine their own community ("imagined communities" cf. ANDERSON, 1983) - whether a nation or an ethnic community - paves the way for emphasizing certain features which are shared among the members of this group. At the same time, this selection is powerful enough to exclude people living in the same place (as has already been the case in ancient Athens, see the above example), or to deny access to resources for neighbours living close to the terrritory that the community is claiming exclusively for themselves.

\section{Their Social Identity}

As mentioned earlier, the group claiming hegemony over other people in the same space constructs its own identity based on their autochthoness. Belonging to this group empowers its prospective members, which at the same time affects their personal identity in a positive way. They imagine themselves as strong and superior with respect to outsiders, who at best form for themselves another group defined by their position in the minority.

Summing up, in order to construct a powerful community, speakers filter their perception and together develop favorable interpretations in order to position their own (often majority, but not always) group as superior to the others. In doing so, they evaluate the speech acts they are listening to, and whether the interlocutor is performing the expected language use or not. Applying the principles of contiguity, and to a lesser extent similarity and contrast, they relate language, speakers and place in such a way that they erroneously treat language and place as inevitably closely related, thus constructing a linguistic-spatial knowledge (Fig. 2) which is embedded in a conception of spatiality as being an essential part of language use. 
Figure 2. Parts of the linguistic-spatial knowledge underpinning the claims of autochthony.

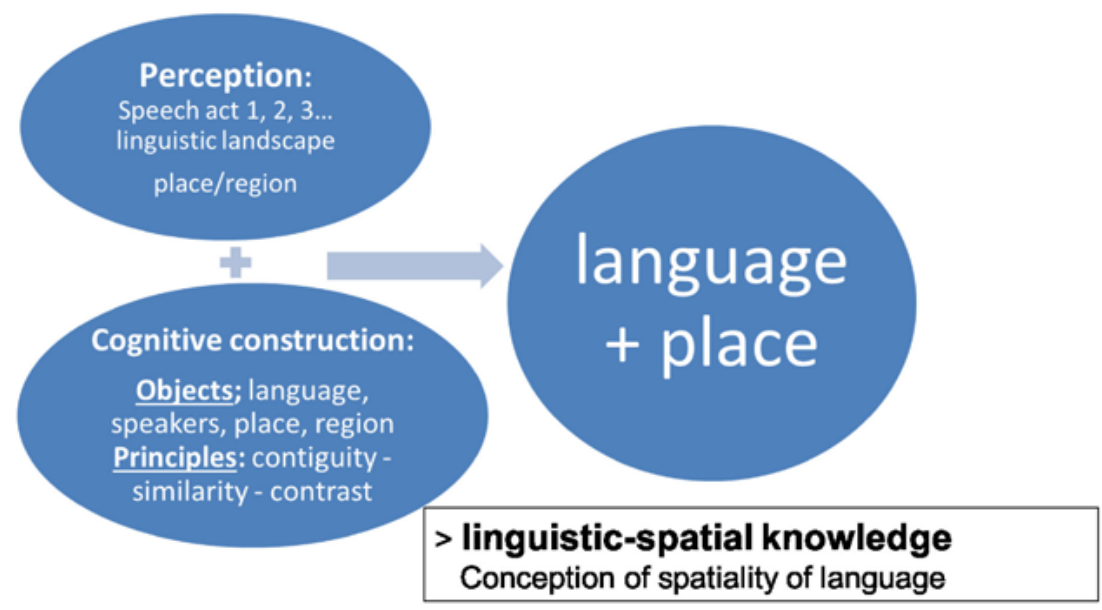

\section{Allochthonous: Ancient and recent migrations}

If we consider some people to be autochthonous, how can we characterize the individuals who are not? In looking for an answer, the term allochthonous first comes to mind; it has long been used as a harsh opposite to the former. Only in (post-)modern times have the terms evolved to form the poles of a continuum, thus allowing for a gradation between the two attributes (TACKE, loc. cit., 2015).

An example of the binary opposition may be found not only in Ancient times, but also in early modern times in the context of the spread of Latin beyond the borders of Italy. In the vast Roman Empire, people not assimilating to neo-Latin Romance Languages, and instead continuing to speak, for example, Celtic or Frankish, represent the autochthonous inhabitants. They preferred to continue using their heritage language (varieties) instead of assimilating to the language introduced by the Romans. Today, the South Tyroleans who continue to speak their German variety in parts of the Italian Alps are autochthone compared with the Italians acquiring Italian as their first language.

Nowadays, it is interesting that especially countries with an important flow of incoming migrants in recent times, such as Canada, are ready to consider people as autochthone when living some time - at least for several generations - in a given 
location. Following Tacke's proposal (Fig. 3) of re-organizing the synonym and its antonym as part of a continuum (2015), the most minimal time span for being autochthonous covers approximately one hundred years corresponding to four generations (minimally autochthonous).

Figure 3. Introducing autochthony as a gradual category (TACKE, 2015, p. 115).

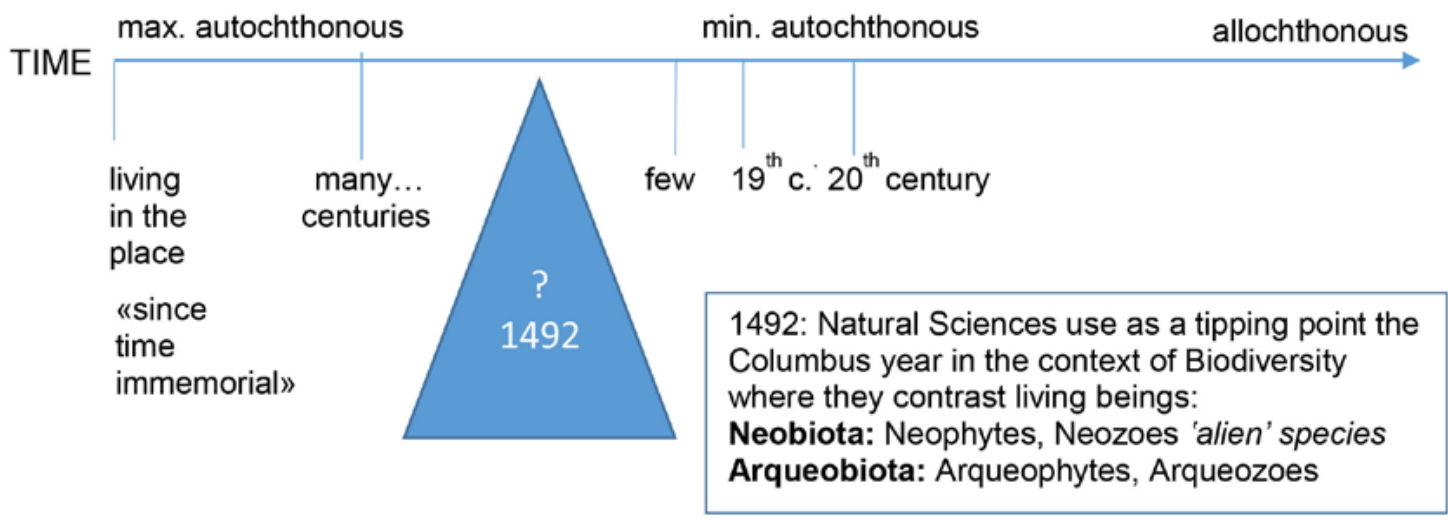

At this point, I insert an instructive side note with the aim of encouraging interdisciplinary discussion. In the Natural Sciences, namely biology, the discussions on environmental issues have researchers still adopting a binary opposition when using the same term autochthonous. They consider those species as autochthonous as those who belong to the location under consideration prior to the date of Columbus' first voyage to America, 1492. They contrast these archeobiota with the other ones called Neobiota, further differentiated into Neophytes, for the plants, and Neozoes, for the animals. For contact between people, this date may be as important as it is for recognizing alien species in Europe or America or in other places, but the decision in cultural terms is far from being unanimous.

\section{[Neo-]Autochthonous Communities}

Returning to our argumentation on the gradation of more or less autochthonous people, we consider now two German communities living outside of Germany. We compare 
${ }^{4}$ Citation from the website of the American Historical Society of Germans from Russia (update 17031999). Disponível em: <http:// depts.washington. e d u / h e rit a g e / Organizations/Russia/ Seattle.htm>. Acesso em 12/01/2017.

${ }^{5}$ e.g. cattle breeding or poultry farming.

$685 \%$ of Russian Germans lived in the European part of Russia before their deportation. I am deeply grateful to Peter Rosenberg for this comment and several suggestions for adjustments concerning the historical context of this group. He is expert and a great researcher on the langague use of these speakers in Russia (ROSENBERG, 2003, p. 2015).

${ }^{7}$ E.g. Pommeranian learned by Dutch L1 speakers in Santa Maria de Jetibá, estado Espírito Santo, Brazil. Similar language acquisition patterns are reported of Swiss German speakers. their language maintenance in the former Soviet Union with that in Brazil, with the aim of sketching two examples of neoautochthonous communities. Germans started to migrate to Russia after 1763 when the population suffered utter poverty after the Seven Years War.

From 1763 to 1767 more than 6,000 families, mostly from Hesse and the Rhineland, emigrated to the Volga. Later (18121842), others from South Germany settled along the Black Sea. Then (1816-1881) more Germans settled in Volhynia. ${ }^{4}$

There was no migration to Brazil in the $18^{\text {th }}$ century, but in the $19^{\text {th }}$ century the accelerated process of industrialization urged them to leave the country. In the countryside, as well as in the urban centers, the introduction of automatization to agrarian and industrial work processes severely endangered the circumstances of workers and peasants and their families, who had to search for new possibilities to earn their living in great numbers. In this historical context, recruitment countries such as Brazil were looking for strong, experienced and reliable farmers to convert previously uncultivated land into arable tracts, with the goal of cultivating corn and vegetables, among other related agrarian activities.

In the new countries, whether in South America or in the different regions of Russia, the Caucasus or later on in Siberia ${ }^{6}$, for several generations they went on speaking their German dialects. Most groups incorporated speakers of diverse dialectal backgrounds, which often led to convergence among the formerly used German dialects, a process accelerated in the context of language contact with the official languages: Russian in the Soviet Union, and Brazilian Portuguese in South America. However, in some places, a certain majority varieties of German, e.g. Pommeranian, or, mostly, Hunsrückisch, turned out to become the media of communication for all members of the community, and was even eventually learned as a second language by neighbours ${ }^{7}$.

Nowadays, the maintenance of German or one of its varieties is no longer the norm. Due to increasing mobility and the ongoing process of integration of former minorities into the respective majority society (which was facilitated by an improvement of the infrastructure, of communication and of education), the young generation, often migrating to 
8 "Und was ist mit den eigenständigen, $\mathrm{k} \mathrm{u} \mathrm{l} \mathrm{t} \mathrm{u} \mathrm{r} \mathrm{e} 11$ e n Sprachvarietäten des Russlanddeutschen? Sind die für immer verloren oder ist es eine wertvolle Aufgabe, sie zu pflegen und z.B. der jungen Generation der Minderheit anzubieten, sie zu erlernen?" (BEREND; EICHINGER, 2013, p. 237)

${ }^{9}$ The historical context is not taken sufficiently into account when the two authors only refer to Platt. We suggest to consider different varieties of Low German instead.

10 "Streng genommen: ja. Denn nichts anderes geschieht ja bei anderen autochthonen [Sprachgemeinschaften] Man könnte sich fragen, ob es nicht einen Weg gibt, an die eigenen Traditionen anzuknüpfen. Könnte nicht der Unterricht des Deutschen für Minderheiten in den Heimatgebieten doch auch darauf Rücksicht nehmen, dass die traditionell dort benutzte Form des Deutschen Anklänge an niederdeutsche, hessische und andere deutsche Mundarten zeigt, um so das Spezifische der eigenen Tradition zu betonen?" (BEREND; EICHINGER, 2013, p. 237).

11 Altenhofen 01/2016 with reference to Wiesinger 1983. nearby cities, calls into question the everyday use of their heritage language.

Firstly, let us have a look at the Germans in the former Soviet Union, and secondly at the Germans in some of the Southern estados of Brazil.

\section{Germans in the former Soviet Union}

In the Siberian context, for example in Barnaul and other places, the Russian Germans developed in their language island over time divergent language varieties different from the earlier ones brought along by their ancestors and former migrants. Unsurprisingly, their forms of expression developed in their unique language contact situation via a different process of language change in contrast to the varieties spoken in Germany. Nowadays, the speakers are in the process of abandoning the use of their unique German varieties, and linguists have started to defend the value of the collectively developed language by ascribing an autochthonous status of its own right to their way of speaking. Nina Berend und Ludwig M. Eichinger (2013) ask the following questions:

And what happens with the unique, cultural language varieties of the Russian Germans? Will they be lost for ever or is it an important issue to give continuity to their practice for example by offering to the young generation of the minority the possibility to learn it? ${ }^{8}$ Strictly speaking: yes. Nothing else happens in other autochthonous language communities. One should find a way to keep the connection with their own traditions. Couldn't the instruction of German for the minorities in their regions of origin show respect towards the unique traditional form of their German which shows traces of Platt ${ }^{9}$, Hessian and other German dialectal varieties with the aim to accentuate the uniqueness of their own tradition? ${ }^{10}$ (BEREND; EICHINGER, 2013, p. 237)

\section{Germans in Brazil}

The ancestry of the Germans who migrated to Brazil is similarly varied. Following Altenhofen ${ }^{11}$, the most popular groups, called big matrix groups and having important settlement areas in Brazil, were the Hunsrückisch, the Rhinelanders, Westphalians and Pommeranians. There are 
12 Cf. The Brazilian government adopted a new law in 2007 regarding the coofficialization of European and other migrant's languages at the level of first instruction in the context of the municipalities: Lei Municipal 987 de 27 de junho de 2007. The municipalities are responsable for first education, namely alphabetization of their local residents. For example Pommeranian has been codified and is integrated in the curriculum of (pre-) school instruction of children until the age of 10 in the municipio of Pancas, Estado Espírito Santo, and in a slightly different form in the one of Santa Maria de Jetibá-ES (Lei Municipal 1136 de 26 de junho de 2009). Furthermore, $\mathrm{Hunsrückisch}$ is used at school in the municipalities of Antônio Carlos and Santa Maria do Herval, both belonging to the Estado Santa Catarina (Projeto legislativo 132 de 9 de fevereiro de 2010). Similar activities happen among the Italian descendents talking Talian, which has its roots mainly in the dialect called Veneto. In order to encourage Brazilian researchers to compile an inventary of linguistic diversity, the Brazilian government issued the Decreto $n^{\circ}$. 7.387, de 09 de dezembro de 2010: Inventário Nacional da Diversidade Linguística (INDL). There Italian Brazilians are especially prominent as Talian forms already part of the INDL (Morello 2012, 34; Gaio forthcoming). Furthermore, since several years Italian based Talian is registered as immaterial historic and artistic patrimony at the Instituto do Patrimônio Histórico e Artístico Nacional (IPHAN). smaller language islands, a name which refers to their rather isolated settlements in the past (cf. ROSENBERG, 2015), formed by Swabians, Swiss, Bavarians and Austrians, still important in number and categorized as matrix groups as well. Even smaller settlements formed by migrant groups are populated by Mennonites, Bohemians, Bukovinians, Silesians, Kashubians and German Russians.

In contrast to the post-Soviet context, the dynamics in Brazil are embedded in a change of language politics towards all types of minority language speakers since 200712, with several earlier steps regarding bilingual education and related activities. Nowadays the society there is paying attention and giving value to language varieties different from Brazilian Portuguese spoken by communities in Brazil by considering them as part of the shared historical and artistic patrimony of the nation (cf. JUNGBLUTH, 2016). The new self-ascribed image of Brazilian society as a multilingual and pluricultural society is built upon its cultural and, most importantly, linguistic diversity. As does Canada, Brazil regards languages and their speakers as autochthonous when the community is known as using its unique form of expression at least by three generations in Brazilian territory (MORELLO, 2012). This view is in line with the aforementioned postmodern interpretation, melting the contrast between allochthonous and autochthonous into a gradatum. In this interpretation, several grades of being considered autochthonous are positioned, as presented by Tacke (2015), who shows consistently with the Brazilian data a tipping point at the beginning of the last century.

\section{Ethnicity in Motion: becoming autochthonous}

We have seen not only that the different political contexts shape different forms of self-awareness among the communities of German origin, which I propose to call neoautochthonous in order to distinguish them from other ethnic groups anchored for centuries already to their territory. The attribute may become important as it offers a potential for a take-off to change the status of their group into a migrant minority. Nevertheless, the language usage they developed in their environment in Siberia or in Southern Brazil is unique, and in this regard 
represents an immaterial patrimony belonging to their place of settlement. As such, it becames a part of the national context in both countries. In my view, it is striking how the countries in the Americas which are interested in the integration of migrants already living in their territory for three or more generations seek to reinterpret ancient terms of belonging in a new way through adapting them to the postmodern political context. In doing so, they not only empower the members of the communities and the ethnic groups they belong to, but at the same time position their nation in a favorable way to attract again and again people from all over the world, very much like the way a new brand attracts customers.

\section{REFERENCES}

ALTENHOFEN, C. V. Hunsrückisch in Rio Grande do Sul: Ein Beitrag zur Beschreibung einer deutschbrasilianischen Dialektvarietät im Kontakt mit dem Portugiesischen. Stuttgart: Steiner, 1996.

. Die Sprachkarte als "Lupe" zur Erkennung von Sprachwandel und Variation: Pluridimensionale Makroanalysen am Beispiel des Hunsrückischen in Südamerika. Apresentação no Colóquio Mehrsprachigkeit und Minderheitensprachen, Frankfurt (Oder): EUV, 01/2016.

ANDERSON, B. Imagined Communities: Reflections on the Origin and Spread of Nationalism, London: Verso 1983. German Translation: Die Erfindung der Nation. Zur Karriere eines folgenreichen Konzepts. Berlin: Ullstein, 1988.

ARACIL, L. Conflit linguistique et normalisation das l'Europe nouvelle. Perpignan: Centre Universitaire de Perpignan. Faculté Pluridisciplinaire des Sciences Humaines et Sociales Institut de Recherche en Sciences de la Communication et de l'Éducation (I.R.S.C.E.), 1976.

BAKKER, P.; MATRAS, Y. Introduction. In: BAKKER, P.; MATRAS, Y. (eds.). Contact Languages. A Comprehensive Guide. Series: Language Contact and Bilingualism [LCB] 6; Boston/ Berlin: De Gruyter, 2013. p. 1-14.

BARNI, M.; EXTRA, G. Mapping Linguistic Diversity in Multicultural Contexts, Berlin: Mouton De Gruyter, 2008. 
BEREND, N.; EICHINGER, L. M. Verlust deutscher Sprachbindung. Herausforderung für kultureller Rehabilitierung. Nordost-Archiv. Zeitschrift für Regionalgeschichte, n.21, 226-238, 2013.

CHYLINSKI, E.; HOFMANNOVÁ, M. (eds.). Ready for Ratification. Early Compliance of non-State Parties with the European Charter for Regional or Minority Languages. A Handbook with twenty proposed instruments of ratification. 2 vol. Flensburg: European Centre for Minority Issues (ECMI), 2011.

COSTA, D. A. da; PEREIRA, T. A aprendizagem do português como língua de inclusão em contexto de imigração haitiana no Rio de Janeiro. In: COSTA, D. A. da; PEREIRA, T.; SA, R. L. de (eds.), Português Para Falantes de Outras Linguas: Interculturalidade, Inclusão Social e Políticas Linguísticas. Belo Horizonte: Editora Pontes, 2016.

FERNÁNDEZ-VILLANUEVA, M.; JUNGBLUTH, K. (eds.). Beyond Language Boundaries, Multimodal Language Use in Multilingual Settings. Berlin/Boston: De Gruyter, 2016.

GAIO, M. L. M.; JUNGBLUTH, K. Etnicidade em movimento. Processos linguísticos e culturais da imigração italiana no Brasil no eixo Rio de Janeiro-Juiz de Fora. In: BORN, J; LADILOVA, A.; SCHÖN, K.; LESCHZYK, D. (eds.). Sprachen, Kulturen und Politik in Bewegung: Umbrüche, Aufbrüche und Kontakte in der Lusophonie. Frankfurt am Main/Bern/Bruxelles/New York/ Oxford/Warszawa/ Wien: Peter Lang. No prelo.

GAIO, M. L. M. Manutenção e perda das línguas e culturas italianas de imigração no eixo Rio de Janeiro-Juiz de Fora. In: Anais do Simpósio Mundial de Estudos de Lingua Portuguesa (SIMELP), Simpósio 47 - Português do Brasil: história, contatos e variedades. No prelo.

Transculturalidade: etnicidade em movimento no contato linguístico-cultural de línguas de imigração - italianos no eixo Rio de Janeiro-Juiz de Fora, Niterói/Frankfurt (Oder): Tese de doutorado co-tutela UFF/EUV. No prelo.

HÖFLER, C. M.. Group belonging beyond language boundaries: Language, religion and identity in the multilingual Greek community of Georgia. STUF 69(2), 213-234, 2016. 
JUNGBLUTH, K. “Nacionalidade é brasileira [...] aber coração chora pros dois". Co-construções bilíngues - atos de identidades biculturais. In: Anais do Simpósio Mundial de Estudos de Lingua Portuguesa (SIMELP), Simpósio 47 - Português do Brasil: história, contatos e variedades. No prelo.

JUNGBLUTH, K. Comparando o uso das línguas pelos falantes de minorias linguísticas: o caso dos descendentes alemães em Brasil e o caso dos gregos em Georgia. Cadernos de Letras da UFF, v.26, n.53, 211-229, 2016.

Crossing the Border, Closing the Gap: Otherness in Language Use. In: JUNGBLUTH, K.; ROSENBERG, P; ZINKHAHN RHOBODES, D. (eds.), Linguistic Construction of Ethnic Borders, Bern/Frankfurt a.M.: Peter Lang. 2015. p. 209-227. Sprechen - sprach - gesprochen: Deutschsprachige Minderheiten in Brasilien und griechisch- und urumsprachige Griechen in Georgien. In: EILERS, Vera / SERAFIN, Stefan (eds.), Vivat diversitas - Romania una, linguae multae. Festschrift für Isabel Zollna. Stuttgart: Ibidem. No prelo.

JUNGBLUTH, K.; ROSENBERG, P; ZINKHAHN RHOBODES, D. (eds.), Linguistic Construction of Ethnic Borders, Bern/Frankfurt a.M.: Peter Lang. 2015.

KOCK KOBAIDZE, M.. Minority identity and identity maintenance in Georgia. Working Papers, n.47, Lund University, Dept. of Linguistics, 149-168. 1999.

KREMNITZ G. Du «bilinguisme» au «conflit linguistique». Cheminement de termes et de concepts. Langages, $15^{\mathrm{e}}$ année, n.61, 63-74, 1981.

KUPER, A. The Return of the Native. Current Antropology, n.44, 389-402. 2003.

LAUDIEN, S. Halb das Blut ist Deutsch und nacionalidade é brasileiro, então sind wir so durchgeschnitten ne, aber coração chora pros dois. Eine empirische Studie zum Code Switching in einer deutschen Sprachinsel Brasiliens. Frankfurt (Oder): EUV. Dissertação de mestrado, 2010.

LESSER, J. A Invenção da Brasilidade. Identidade Nacional, Etnicidade e Políticas de Imigração. São Paulo: UNESP. 2015.

Negotiating National Identity: Immigrants, Minorities, and

the Struggle for Ethnicity in Brazil. Durham, NC: Duke University Press. 1999. 
LOLADZE, N. Greeks of Georgia: Main factors and motivations of emigration. STUF, p.69-2, 2016.

LÜDI, G.; SEELMANN, K; SITTER-LIVER, B. (eds.). Sprachenvielfalt und Kulturfrieden. Sprachminderheit-Einsprachigkeit - Mehrsprachigkeit: Probleme und Chancen sprachlicher Vielfalt, Fribourg, Stuttgart: Academic Press, Kohlhammer, 2008.

MASELKO, M.; HAMESTER, J.; SOLANGE, M.; DEWES, M. Hunsrik lërne 'Hunsrückisch lernen'. Dialektunterricht in der deutschen Sprachinsel Südbrasiliens. The Journal of Languages for Specific Purposes, n.1, 95-106, 2014. Disponível em: < http:// jlsp.steconomiceuoradea.ro/archives/001/jlsp-i1-9.pdf $>$. Acesso em: 21 jan. 2017.

MORELLO, R. Uma política pública e participativa para as línguas brasileiras: sobre a regulamentação e a implementação do Inventário Nacional da Diversidade Linguística (INDL). Gragoatá, v.17, n.32, 31-42, 2012.

PFAFF-CZARNECKA, J. From 'identity' to 'belonging' in Social Research: Plurality, Social Boundaries, and the Politics of the Self. In: ALBIEZ, S.; CASTRO, N.; JÜSSEN, L.; PFAFFCZARNECKA, J; YOUKHANA, E. (eds.). Ethnicity, Citizenship and Belonging: Practices, Theory and Spatial Dimensions. Madrid: Iberoamericana, 2011. p. 199-219.

Multiple belonging and the challenges to biographic navigation. Max-Planck-Institut zur Erforschung multireligiöser und multiethnischer Gesellschaften, Göttingen, MMG Working Paper, WP 13-05, jan. 2013. Disponível em: <http://www.mmg.mpg. de/fileadmin/user_upload/documents/wp/WP_13-05_PfaffCzarnecka_Multiple\%20belonging.pdf $>$. Acesso em: 21 jan. 2017. ROSENBERG, P. Comparative speech island research: Some results from studies in Russia and Brazil. In: KEEL, W.; MATTHEIER, K. J. (eds.). Deutsche Sprachinseln weltweit: Interne und externe Perspektiven. German Language Varieties Worldwide: Internal and External Perspectives. Bern/Frankfurt am Main: Peter Lang. 2003. p.199-238.

Anything goes? The gains and losses of the constructivist view on ethnicity: Some considerations based on German 'language islands' studies. In: ROSENBERG, P.; JUNGBLUTH, K.; ZINKHAHN RHOBODES, D. (eds.). Linguistic Construction of Ethnic Borders. Bern/Frankfurt am Main: Peter Lang. 2015. p.149-166. 
ROSIVACH, V. Autochthony and the Athenians. The Classical Quarterly, 37(2), 294-306. 1987.

SAVEDRA, M. M. G.; HÖHMANN, B. Das plurizentrische Deutsch in Brasilien und die regionale Kooffizialisierung eines ostniederdeutschen Dialekts. In: SCHNEIDER-WIEJOWSKI, K.; KELLERMEIER-REHBEIN, B.; HASELHUBER, J. (eds.). Vielfalt, Variation und Stellung der deutschen Sprache. Berlin: De Gruyter. 2013. p. 411-426

TACKE, F. Sprache und Raum in der Romania. Beihefte der Zeitschrift für Romanische Philologie 395. Berlin/Boston: De Gruyter, 2015.

TRACY, R.; LATTEY, E. It wasn't easy but irgendwie äh da hat sich's rentiert, net?: A linguistic profile. In: ALBLMIKASA, M.; BRAUN, S.; KALINA, S. (eds.). Dimensionen der Zweitsprachenforschung. Tübingen: Narr. 2010. p.53-73.

TRÉSOR DE LA LANGUE FRANÇAISE: Dictionnaire de la Langue de XIXe et du XXe siècle (1789-1960), Paris: Centre de Recherche pour un Trésor de la Langue Française. 16 vols. from 1971 to 1994.

VOGELSANG, S. Die Sprachpolitik Japans und Singapurs im Vergleich: Mono vs. Multi?. Frankfurt (Oder): Europa-Universität Viadrina: Dissertação de mestrado, 2016.

ZENKER, O. Autochthony, Ethnicity, Indigeneity and Nationalism: time-honouring and state-oriented modes of rooting individual-territory-group trias in a globalizing world. Critique of Anthropology, n.31, 63-81. 2011.

ZINKHAHN RHOBODES, D. Sprachwechsel bei Sprachminderheiten: Motive und Bedingungen: eine soziolinguistische Studie zur deutschen Sprachinselminderheit in Blumenau, Brasilien. Stuttgart: Ibidem, 2012.

ZOUMPALIDIS, D. Us and them: Inter- and intra-communal ethno-linguistic borders within the Pontic Greek community in Cyprus. STUF 69(2), 235-253. 2016.

. Russian language - Greek identity: A sociolinguistic approach to the Pontic Greek community in Russia. In: SMYTH, Sarah; OPITZ, Conny (eds.). Negotiating linguistic, cultural and social identities in the post-Soviet world. Bern/Berlin: Peter Lang, 2013. p. 227-245. 


\section{Resumo}

Etnicidade em movimento: construindo brasilidade ao conceder o estatuto de autóctones aos primeiros imigrantes

O artigo apresenta a perspectiva pós-moderna na autoctonia a partir de uma abordagem teórica. O contraste antes estabelecido entre povos alóctones e povos autóctones sofreu uma mudança; na atualidade, os pesquisadores propõem que as duas qualidades formam os polos de um contínuo, no qual podem ser distinguidos diferentes níveis de existência autóctone. Como o Canadá, o governo brasileiro também abriu o caminho, concedendo o estatuto de autoctonia a comunidades linguísticas vivendo por até três gerações no país. Ao reconhecer a diversidade cultural e ao mesmo tempo linguística como um elemento essencial ao processo de construção de uma nova imagem do brasileiro, a brasilidade (LESSER, 2015), o uso linguístico especial desenvolvido pelos descendentes de imigrantes europeus é agora considerado parte do patrimônio artístico e histórico imaterial na América do Sul.

Palavras-chave: Brasil. Uso linguístico. Autóctone. Política linguística. Bilinguismo. 